\title{
Финансовое положение России при Временном правительстве В 1917 г.: новый взгляд на историографию вопроса
}

\author{
И.М. Пушкарёва \\ Институт российской истории Российской академии наук, \\ Россия, 117292, г. Москва, ул. Дмитрия Ульянова, д. 19 \\ E-mail: pushkarev@mail.ru
}

\begin{abstract}
Аннотация. В статье отражена история финансов России при Временном правительстве в 1917 году. Обобщающая достижения российской историографии, она обращает внимание на общие черты политики Временного правительства, на роль банков в обстановке ухудшения экономического положения народа в стране, на взаимоотношения России с союзниками в Первой мировой войне - Англией и Францией. Бессилие правительства в обстановке политического кризиса толкало тех, кто имел доступ к экономическим рычагам управления, к радикальным мерам: распродаже национальных богатств, к свободному доступу в страну представителей иностранного капитала. В особенности привлекательными казались им богатые ископаемыми сибирские земли, золотоносные рудники Алтая, окраинные земли на Дальнем Востоке, острове Сахалин. Автор убежден, что остановить «кровопускание российской финансовой системы» могли только радикальные усилия крепкой государственной власти.
\end{abstract}

Ключевые слова: Первая мировая война, Временное правительство, финансы, налоги, займы, инфляция, золотой запас, страны-союзники России, концессии.

Для цитирования: Пушкарёва И.М. 2020. Финансовое положение России при Временном правительстве в 1917 г.: новый взгляд на историографию вопроса. Via in tempore. История. Политология, 47 (4): 836-853. DOI: 10.18413/2687-0967-2020-47-4-836-853.

\section{The financial status of Russia under Provisional government in 1917: historigraphy revisited}

\author{
Irina M. Pushkareva \\ Institute of Russian History, Russian Academy of Sciences, \\ 19 Dmitry Ulyanov St., Moscow, 117292, Russia \\ E-mail: pushkarev@mail.ru
}

\begin{abstract}
The article highlights the contradictory history of Russian finance system during the rule of the country by the Provisional Government in 1917. Summarizing the achievements of Russian historiography, author draws attention to the general features of the policy of the Provisional Government, to the role of banks in an environment of deteriorating economic situation of the people in the country, to Russia's relations with England and France which were its allies in the First World War. The impotence of the government in the midst of the political crisis pushed those who had access to economic levers of government to radical measures: the sale of national wealth, to the permission of free access for representatives of foreign capital to the country. The Siberian lands rich in minerals, the goldbearing mines of Altai, the outskirts of the Far East, Sakhalin Island seemed especially attractive to them. The author is convinced that only radical efforts of a strong state power could stop the «bloodletting of the Russian financial system».
\end{abstract}

Keywords: First World War, Russian Provisional Government, finances, taxes, loans, inflation, gold reserve, allies of Russia, concessions. 
For citation: Pushkareva I.M. 2020. The financial status of Russia under Provisional government in 1917: historigraphy revisited. Via in tempore. History and political science, 47 (4): 836-853 (in Russian). DOI: 10.18413/2687-0967-2020-47-4-836-853.

Обращение к столетию Первой мировой войны и революций 1917 г. требуют подведения не только общего, большей частью умозрительного итога в отечественной науке, но привлечения внимания к разработке отдельных тем, одной из которых является финансовое положение России.

С приходом к власти 3 марта 1917 г. Временного правительства в России, сменившего имперский режим, начинался второй период в истории финансов в мировую войну в ходе дальнейшего развития второй демократической революции в стране. Отправным моментом историографического исследования в данной статье являются соответствующие главы монографии П.В. Волобуева 1962 г. [Волобуев, 1962, с. 301], комментарии к ней с позиции сегодняшнего дня, реализованные возможности дополнений ее в новейших исследованиях.

Ученик и последователь А.Л. Сидорова П.В. Волобуев продолжил хронологически его изучение финансового положения России в годы Первой мировой войны [Сидоров, 1960] через призму экономической политики Временного правительства. Обращение сегодня к этой теме представляется актуальным в научном и политическом аспекте, имея в виду сложные сегодня международные отношения России со странами Европы и США. П.В. Волобуев исходил из представления о финансовом положении России в войну в трудах 1917-1918 гг. современников - Г.Д. Дементьева, Д. Боголепова, С.Н. Прокоповича и других историков, экономистов, политиков, которым удалось «прочувствовать» и представить Россию того времени [Боголепов, 1917; Дементьев, 1917; Прокопович, 1918].

В советской историографии 1940-1950-х гг. Волобуев отдал должное книгам В.П. Дьяченко, Б.Б. Ривкина, А. Коняева [Дьяченко, 1947; Ривкин, 1957; Коняев, 1959], которые уделили внимание состоянию финансов в 1917 г., налоговым мероприятиям Временного правительства, роли банков в падавшей в целом экономике России. Характеризуя более поздние работы своих предшественников с точки зрения освещения финансов в 1917 г., П.В. Волобуев выделяет статьи Р.Ш. Ганелина и Л.Е. Шепелева [Волобуев, 1962, c. 13] и ставит проблему способности русской буржуазии к самостоятельному историческому творчеству и, в частности, ее представителей в правительстве в 1917 г. руководить Министерством финансов. Его вывод сводился к тому, что финансовое положение было таковым, что у России был один путь - к социализму.

После выхода монографии П.В. Волобуева финансовым проблемам Временного правительства, как и в целом экономическому положению страны в 1917 г., внимание практически не уделялось. На это указывают сегодня Ю.П. Голицын и Ю.А. Петров в коллективном труде к столетию революции 1917 г. [Голицын, Петров, 2017, с. 384-453], вобравшем исследование проблемы с конца 80-х гг. при проявленном интересе к золотому запасу страны в 1917 г. [Ефимкин, 1988, с. 105-110]. В 90-е гг. в поле зрения исследователей оказались фондовый рынок, государственный долг, иностранные инвестиции, денежное обращение, займы 1917 г. [Потемкин, 1997; Голицын, 1998; Петров, 2000; Денисов, 2005; Страхов, 2007; Вознесенский, 2009; Ходяков, 2009; История Банка, 2010; Мошенский, 2014 и др.]

Сегодня выделяются два направления, позволившие рассуждать на тему о финансовом положении России при Временном правительстве: 1) его финансовая политика и 2) проблема подчиненности Государственного банка. При этом главной задачей является (и здесь не обойтись без обращения к имперскому периоду периода войны) выяснение надежности для экономики России финансовой системы в период Первой мировой войны. 
В финансовом секторе Временного правительства (разделившего новую власть с Петроградским Советом рабочих и солдатских депутатов) возникли большие трудности. Первостепенная задача, которую Министерство финансов при всех кадровых перестановках пыталось решить в течение всего 1917 г., состояла в том, чтобы сохранить при денежном обращении деятельность народнохозяйственного организма. Временное правительство унаследовало от имперского обязанность перед союзниками. Оно считало для себя главной задачей искать средства, чтобы работать на «молох» войны для бессмысленного для страны ее продолжения, уже обескровленной огромными людскими потерями.

2 марта 1917 г. Министерство финансов возглавил юрист по образованию, недавний чиновник при дирекции императорских театров, крупнейший землевладелец, хорошо известный в деловом мире русской буржуазии политический деятель (по слухам - масон) М.И. Терещенко. Его детищем в поисках средств, со слов управляющего делами Временного правительства, стала с 5 марта 1917 г. реализация «Займа свободы». Терещенко всецело сосредоточился на его проведении в стране.

8 марта Временное правительство открыто признало специальным заявлением все финансовые обязательства прежней власти по внешним государственным займам, а также по внутренним - вкладам в сберегательные кассы и др. «Все платежи, следующие в казну, налоги, пошлины и иные всякие поступления должны вноситься по-прежнему, впредь до изменения их законом» [Вестник, 1917; Экономическое положение, 1957, с. 394].

Предприятие, печатавшее бумажные деньги, так и оставалось едва ли не единственным не военным в стране, резко расширившим объем производства [Вознесенский, 2009 , с. 386]. Продолжали распространяться новые кредитные билеты после Февраля 1917 г. в сумме 8285 млн руб. В 1914 г. эта сумма равнялась 1665 млн руб., а к марту 1917 г. поднялась до 9950 млн руб. Внутренние государственные военные займы выросли до 8 млрд руб., займы у западных стран приближались к 7,5 млрд руб. Государственный долг возрос с 8,8 млрд руб. в 1914 г. до 33,6 млрд руб. еще в 1916 г., а золотой запас страны продолжал исчезать в банковских хранилищах союзников.

Осознавая угрозы бумажной эмиссии как инфляционного фактора, Министерство финансов возлагало надежды на внутренние и внешние займы, ослабляющие выпуск бумажных денег, на реализацию «Займа Свободы», о котором существует большая литература. О нем вспоминал Н.Н. Суханов [Суханов, 1922, с. 220-221], в 1918 г. С.Н. Прокопович [Прокопович, 1918, с. 122, 200 и др.], подчеркивая кризис экономики, вызванный войной. Внимание к «Займу Свободы» в советской историографии начиная с 20 -х гг. объяснялось широко практикуемой в СССР этой формой пополнения государственного бюджета [Чубаков, 1926, с. 134 и др.; Гусаков, 1946, с.29-32; Ривкин, 1957, с. 45; Сидоров, 1960, с. 151; Погребинский, 1968, с. 259]. П.В. Волобуев уделил внимание этой заемной кампании Временного правительства в связи с историей его кредитной политики, обратившись к архивным и печатным источникам [Волобуев, 1962, с. 338-350]. В 2007 г. к истории «Займа Свободы» снова обратился В.В. Страхов [Страхов, 2007, c. 31-38]. Ю.П. Голицын и Ю.А. Петров выделяют историю «Займа Свободы» Временного правительства («Займа Победы», как изначально он был назван) в связи с расколом в обществе по поводу продолжения войны [Голицын, Петров, 2017, с. 387-389].

Еще до Февраля 1917 г. в России было уже выпущено займов на 8 млрд руб. номинальных, и выручка от них составила 7528,9 млн руб. 9 марта вышли «Общие основания» для выпуска «Займа Победы (Свободы)». Временное правительство и лично Терещенко руководствовались опытом имперского Министерства финансов, его связью с банками. Государственный банк в этом деле играл организующую роль. Заем должен был погашаться тиражами в течение 49 лет начиная с 1922 г. Совместно с крупнейшими частными банками Государственным банком для размещения займа был образован синдикат из 30 ведущих коммерческих банков. Виднейшие финансовые авторитеты сделали его выгодным для помещения капиталов. Подписка на первый заем Временного правительства открылась 6 ап- 
реля на довольно выгодных условиях: было обещано до 5 \%, а фактически он дал в первый год 6,7-8 \% с суммы вложений. Наверное, заем мог бы повлиять положительно на экономическую ситуацию, если бы не общая остановка в стране, глубоко зашедший кризис промышленности, развал продовольственного снабжения, упадок производительности труда, снижение заработной платы, не остывающий революционный процесс.

В расчете на широкий охват населения срок подписки на заем был установлен с 6 апреля до 1 июня 1917 г. и сопровождался призывами спасти «от гибели свободу и достояние страны». Ни один заем в России в Первую мировую войну не рождал в обществе такого столкновения на политической почве, как «Заем Свободы». Отражая подъем революции, он стал своего рода лакмусовой бумажкой отношения людей к войне, а политических партий - к курсу Временного правительства.

Понимая, что заем может спасти Россию от революции, в нем принимали участие бывшие представители власти вплоть до членов дома Романовых, даже семьи Николая II [Голицын, Петров, 2017, с. 390-391].

Партия кадетов встретила «Заем свободы» с одобрением. С воззваниями к подписке на заем обратились видные экономисты, в их числе М.И. Туган-Барановский. Меньшевики и эсеры в Петроградском Совете рабочих и солдатских депутатов в большинстве своем оказали займу поддержку. Председатель Исполнительного комитета Совета меньшевик И.Г. Церетели объявил заем «лучшим средством финансирования революции» [Суханов, 1922, с. 229-221]. Большевики встретили заем критикой, увидев в нем поддержку с помощью народа продолжения войны и заявляя, что лидеры эсеро-меньшевистского Петроградского Совета «беспомощно сдались капиталистам» [Волобуев, 1962, с. 341]. Вопрос о займе после февральских событий в Петрограде провел ощутимый раздел между большевиками и другими социалистическими партиями [Страхов, 2007, с. 31-34, 35, 38].

Хорошо оплаченный правительством Всероссийский комитет общественного содействия государственным займам издавал огромными тиражами десятки агитационных брошюр. Способствовало кампании займа и то, что для его размещения крупнейшие частные банки совместно с Государственным банком образовали специальный синдикат, в который входило 30 коммерческих банков. Для «демократизации» подписки ими предусматривалось предоставление ссуд для приобретения облигаций в учреждениях Государственного банка и казначействах. На улицах городов появились «кортежи из экипажей», агитирующие за заем. У банков возводились разукрашенные киоски, здесь же продавались лотерейные билеты, сулившие выигрыши [Аничков, 1998, с. 56-57].

В обстановке общественной эйфории в начале весны критика большевиками «Займа Свободы» не воспринималась народом; тогда по числу подписчиков - 1 млн человек прохождение его обнадеживало Министерство финансов. К концу апреля Временное правительство и сам Терещенко уже ощутили, что «Заем Свободы» не оправдывает на него надежд, когда вместо ожидаемых миллиардов народных денег оно получило подписку лишь на 725 млн руб. Министр финансов Терещенко, вложив свои средства в организацию «Займа Свободы», практически не занимался более ничем, страхуя свое начинание. Заем не остановил и обременения рынка бумажными деньгами и почти не дал правительству денег. Замечу, что уже летом люди стали отказываться от подписки на заем, и он не становился «народным займом», как на то рассчитывало Временное правительство [Цит. по: Волобуев, 1962, с. 342]. Тогда сумма подписки составила немногим более 4 млрд, в то время когда один день войны обходился в 50 млн руб. [Голицын, Петров, 2017, с. 391] Сумма краткосрочных обязательств составила 10 млрд руб., в казну же поступило 8,19 млрд руб. Произошел только перевод из краткосрочного долга казны в долгосрочный [Страхов, 2007, с. 42-43; Голицын, Петров, 2017, с. 342-343].

23 апреля при Министерстве финансов срочно было учреждено особое Совещание для разработки плана финансового преобразования. Но за два месяца, пока у власти находился первый состав Временного правительства, в области финансов практически оно не 
сделало ничего [Волобуев, 1962, с. 301]. Уходя с поста министра финансов, Терещенко заявил, исходя из своего понимания дел, что «финансовые реформы не могут быть быстро осуществлены» [Цит. по: Шляпников, 1927, с. 105].

Поскольку Терещенко дал личную гарантию на выпуск «Займа Свободы», будучи уже в эмиграции, на протяжении многих лет он погашал долговые обязательства по нему крупнейшим европейским банкам, участвовавшим в его размещении [Терещенко, 2012, c. 199-202].

Замечу, что Терещенко ушел с поста министра финансов 5 мая 1917 г., еще не зная, что ему все-таки придется решать вопросы, связанные с финансовым положением страны осенью 1917 г. в качестве заместителя министра-председателя правительства.

Смена лиц на посту министра финансов при Временном правительстве в течение восьми месяцев заслуживает специального анализа. Чехарда со сменой министров финансов после П.Л. Барка осложняла ситуацию и не лучшим образом влияла на работу министерства. Никто из занимавших кресло министра финансов в 1917 г. не мог сравниться с Барком. После М.И. Терещенко этот пост занял врач по образованию, больше политик, чем финансист, кадет А.И. Шингарев (5 мая - 2 июля 1917 г.).

В связи с приходом в правительство социалистов (меньшевиков и эсеров) историки подчеркивают соответствующие изменения и в Министерстве финансов. Оно демонстрировало решимость повысить доходы у предпринимателей [Голицын, Петров, 2017, с. 396].

Шингарев прежде всего попытался разобраться с расходами на организацию ближайшего наступления на фронте. Вникнув в малоизвестную ему финансовую сферу, он понял, что бюджетные доходы к середине 1917 г., которые были прописаны и существовали на бумаге, представляют «простые бухгалтерские выкладки». В них значилось, что доходы должны увеличиваться в 1917 г., а на деле уже «добрая половина их питается войной». Фиктивными оказались доходы казенных железных дорог за казенные грузы, также как доходы таможни за казенные товары, купленные за границей. Прирост был создан с предполагаемых военных заказов и «не представлял дохода, на который государство могло смотреть как на известный прочный плюс», - подтвердил позже историк Дементьев, и на него ссылается Волобуев. Шингарев констатировал, что, к сожалению, по отношению к широким массам тяжесть обложения налогами в России значительнее, чем в других странах. Он с тревогой отмечал, что ничем, а тем более налогами нельзя покрыть военных расходов. Шингарев предложил провести «сурово» обложение сверхприбыли с военных промышленных предприятий, хотя позднее признался, что это был скорее тактический маневр для получения морального права в обществе на новое косвенное обложение [Волобуев, 1962, с. 310, 314, 319-331, 347, 353 и др.].

13 мая министр труда меньшевик М.И. Скобелев в Петроградском Совете действительно потребовал стопроцентного изъятия в пользу государства прибылей капиталистов и «беспощадного» обложения их имуществ [Страхов, 2006, с. 33]. В развитии этих настроений 12 июня 1917 г. Временное правительство принимает три налоговых закона: «О повышении окладов государственного подоходного налога» (от этого мероприятия правительство надеялось получить в казну сверхприбыль в 680 млн руб.), «Об установлении единовременного налога» и «Об изменении размеров налога на прирост прибылей торгово-промышленных предприятий и вознаграждения личных промысловых занятий». Налоги как бы раскрывали обществу успех революционной перестройки, рассчитывая «умирить» народ, ведь они усматривали громадное повышение налогов на имущих россиян, прокламируя беспрецедентный акт не только российской, но и мировой налоговой практики [Голицын, Петров, 2017, с. 386-387]. Появление их было всецело обязано «июньскому революционному подъему» [Волобуев, 1962, с. 321], как отметил осенью 1917 г. М.В. Бернацкий, ставший министром финансов во Временном правительстве. Ни один из законов не был реализован Временным правительством. Законы отражали состояние общества, попытки лавирования правительства между народом и богатеющей буржуазией и 
не более того. Однако уже само обсуждение налогов на имущих вызвало резкое неприятие темы в деловых кругах, которое грозилось усилиться при одном только напоминании о ней в дальнейшем. П.П. Рябушинский тогда заявил, что Россией «управляет какая-то несбыточная мечта, невежество и демагогия» [Волобуев, 1962, с. 321]. Когда позже, в июне, дошло дело чуть ли не до объявления правительству финансового бойкота, Шингарев заявил, что уйдет, и в июле действительно ушел с поста министра финансов.

Между тем финансовое положение все более осложнялось проблемами подчиненности банковского капитала власти. Вопрос этот назревал еще при имперском правительстве. В конце 1916 г. П.Л. Барк не случайно ставил вопрос о необходимости предоставления Особому совещанию по обороне и его заводским совещаниям начать обследование [Сидоров, 1973: 402] деятельности банков, их торгово-комиссионных операций и прав, которые они имели в отношении торговых и промышленных предприятий [Особые совещания, 1917, с. 13].

В мае 1917 г. при Шингареве этим организациям было разрешено ходатайствовать перед Министерством финансов об обследовании банков для выявления злоупотреблений. Ведомственная проверка банков могла бы осуществить попутно контроль различных сторон хозяйственной жизни страны. Однако авторитетным большинством во Временном правительстве был сделан совершенно определенный выбор между народом и торговопромышленной буржуазией в пользу «священных прав на бешеные прибыли». После чего последовало распоряжение МВД общественным организациям, запрещающее устанавливать контроль деятельности крупных банков. Позаботилось правительство тогда и об охране банковской тайны, которой более всего дорожил финансовый капитал, всеми мерами противясь отмене коммерческой тайны [Волобуев, 1962, с. 89-91].

Министерство Шингарева первого коалиционного правительства не справилось и с «Займом свободы», проваленным в конце мая, промышленной буржуазией и банками, развернувшими защиту своих капиталов. В итоге тот состав Министерства финансов пришёл к необходимости новой бумажной эмиссии.

После правительственного политического кризиса в июле и двухнедельного перерыва, когда дела в министерстве решал его управляющий А.Г. Хрущов (11-24 июля 1917 г.), портфель министра финансов получил член Особого совещания по обороне кадет Н.В. Некрасов (25 июля - 31 августа 1917 г.), державший до этого портфель министра путей сообщения.

Некрасов начал с заявления, что «новый революционный строй обходится государственному казначейству гораздо дороже, чем обходился старый строй» [Цит. по: Волобуев, 1962, с. 310]. И Временное правительство далее приступило к обложению косвенными налогами производство и продажу табака, папирос, крахмального сахара, спичек, а затем и к повышению акцизных ставок на продукты массового потребления - чай, спирт, виноградные вина, дрожжи, хотя и не успело провести в жизнь до «низложения» большевиками.

Еще Некрасов не занял министерское кресло, а 19 июля правительство в надежде скорее получить 121 млн руб. объявило, что повышает акцизы на табак, папиросы; причем на махорку более чем на $50 \%$, имея в виду, что они являются самыми выносливыми предметами обложения [Волобуев, 1962, с. 333-335]. Но это вызвало огромный протест, который, хотя и растворился в политических событиях того времени (выступление Корнилова), но остался в памяти определенных слоев народа, и о нем лучше было не заикаться.

9 августа при Некрасове начались переговоры между ведомственными учреждениями о выпуске второго внутреннего 4,5 \% займа. Он был инициирован положением с перевозкой как военных, так гражданских грузов, и был рассчитан на 750 млн руб. [Экономическое положение, 1957, с. 411]. Его реализация пришлась уже на министерство М.В. Бернацкого.

Поскольку еще в мае 1917 г. появились сомнения, а затем становилось все очевиднее, что «Заем Свободы» не оправдал себя, возникали новые проекты займов, в том числе 
принудительных. Такой проект предложил тогда профессор П. Гензель, но он не был даже обсужден в связи с возобновлением военных действий [Голицын, Петров, 2017, с. 393]. В то же время у другой группы при правительстве речь пошла о выпуске военного выигрышного займа на 1 млрд руб. с большим количеством мелких и средних выигрышей [Потемкин, 1997, с. 56 и др.]. Расчет был на поддержку возможно бо́льшего числа подписчиков. От ежегодного погашения тиражей предполагалось отказаться. Это позволило бы избежать быстрого роста рыночного курса облигаций и их конкуренций с другими ценными бумагами [См. подробнее: Вопросы финансовой, 1916, с. 28-37]. Некоторые идеи этих планов были реализованы в принятом 11 августа 1917 г. постановлении о выпуске Министерством финансов внутреннего вышеназванного 4,5 \% выигрышного займа. Предусматривалась эмиссия облигаций сериями по 400 млн руб. каждая, и ежегодно в течение 50 лет (т. е. до 1967 г.) по каждой серии должны были производиться два тиража выигрышей. Облигации должны были погашаться только выпавшими на них выигрышами [Голицын, Петров, 2017, с. 393-394].

Некрасов был удален из правительства в конце августа после столкновения с министром-председателем Керенским, которому тот в резкой форме посоветовал уйти со своего поста после корниловского путча [Тютюкин, 2012, с. 299].

Место министра финансов в третьем коалиционном правительстве занял М.В. Бернацкий (2 сентября - 25 октября 1917 г.), вместе с другими на министерских постах - с А.И. Коноваловым, М.И. Терещенко, А.И. Верховским, Д.Н. Вердеревским, деятельность которых прямо или опосредованно была связана с финансовым положением страны.

Юрист по образованию, министр финансов М.В. Бернацкий работал во Временном правительстве с первых дней его формирования. В июне 1917 г. выступил одним из организаторов новой радикально-демократической партии либерально-центристского толка. Профессор политэкономии, много занимавшийся аграрным вопросом, ближе других стоял к тому, чем должно было заниматься Министерство финансов. Категорически отвергавший безвозмездную эксплуатацию частных земель, их национализацию, он как бы оказался на своем месте. С министром торговли и промышленности А.И. Коноваловым Бернацкий составил программу, связанную с бюджетом, рассчитанную на усиленную поддержку промышленного производства.

В этой программе проявилось понимание финансового положения в стране. В ней был пункт о запрете вывоза русских ценностей за границу, и он мог быть реализован, запрет влиял на действие налоговых законов. Но осуществить выполнение других важных пунктов программы по независящим от ее составителей обстоятельствам было невозможно, слишком скоро менялась обстановка, и предугадать конъюнктуру было невозможно.

Бернацкому и пришлось столкнуться с требованием делового мира «приостановить до уточнения» действие закона 12 июня; его представители буквально «повисли на нем», пока закон не был признан «ошибкой» министра финансов Шингарева и министра труда М.И. Скобелева из прежнего состава Временного правительства.

Стремясь отвлечь печать от обсуждения раздражающих фактов, на основе которых появился закон 12 июня, правительство Керенского подчеркивало в ней свою заслугу введение прямых налогов на имущество как наследство и на предметы роскоши [Волобуев, 1962, с. 329-331].

При Бернацком снова началось размещение выпуска займов, в данном случае второго Объединенного железнодорожного. Первый его выпуск пришелся на осень 1916 г. и был определен на общую сумму 350 млн руб. Была затеяна достаточно крупная финансовая операция. В 1917 г. Министерство финансов объявило о займе в связи с нежеланием коммерческих банков идти на дальнейшее кредитование железных дорог без обеспечения гарантий им дополнительных кредитов в Государственном банке. Заем выпускался из 4,5 \% на 81 год и реализован среди акционеров банков. В нем участвовали 12 частных же- 
лезнодорожных обществ. Заем планировалось погашать тиражами по нарицательной стоимости начиная с 5 сентября 1918 г. [Голицын, Петров, 2017, с. 392]. Подписка началась 3-5 октября, и заем неожиданно был размещен в течение трех дней с превышением выпускной суммы. Объяснялась эта активность растущим слоем предпринимателей, которые получили благодатный объект для спекуляции на фондовой бирже, завуалированной «производительным назначением». П.В. Волобуев пишет, что не последнюю роль сыграло наличие государственной гарантии [Волобуев, 1962, с. 349].

Всеобщая железнодорожная стачка 24-27 сентября, грозившая остановке уже в первый день 39 (49) общих и частных железных дорог и полному параличу экономики, охладила отношение к займу, когда выяснилось, что у Министерства финансов нет денег для повышения новых тарифных ставок по заработной плате для достойной оплаты штатного наемного труда [Пушкарева, 1964, с. 180-202]. Выяснилось, что долг правительства железнодорожникам превышал миллионы рублей.

Результаты прохождения других займов даже в виде обязательств Государственного казначейства, существовавших и до февраля 1917 г., оказались плачевными [Голицын, Петров, 2017, с. 393-394]. Провалы их в советской историографии объяснялись тем, что революция расшатывала и расшатала устои государственного и частного кредита, а это экономический термометр (по Марксу) - показывает интенсивность революции. «В той самой мере, в какой падает кредит, повышается накал революции и растет ее творческая сила... Банки, оказывающие как хозяева частного капитала могучее воздействие на Государственный кредит Временного правительства, понимали необходимость его финансовой поддержки для укрепления власти и возможности продолжения войны. Но в то же время они, напуганные... революцией, не хотели вкладывать свои капиталы без твердой уверенности в том, что они не только получат прибыль, но и вернут эти капиталы» [Волобуев, 1962, с. 345]. Временное правительство было для них плохим гарантом. Отсюда сдержанность предпринимателей и банков к займам. «Как правило, банки использовали кредит как средство давления на правительство с целью решительной борьбы с революцией» [Волобуев, 1962, с. 345]. Если этого не было, то банки уклонялись от финансирования правительственных начинаний. Так был провален и «Заем свободы».

Осенью 1917 г. Министерством финансов была предпринята попытка решения вопроса с ипотечным кредитом. Вместе с заместителем министра-председателя Терещенко Бернацкий подписал распоряжение «Об учреждении Государственного банка городского и земского кредита». Предполагалось, что банки займутся реализацией облигационных займов на внутреннем и внешнем рынках, но до 25 октября они не успели развернуть свою деятельность. Как и предыдущие министры финансов Временного правительства, Бернацкий так и не смог заручиться поддержкой отечественных финансистов [Голицын, Петров, 2017, с. 395]. Этому было две причины. Одна из них - глубоко внутренняя, связанная с экономикой в годы войны в целом.

Материал, поднятый историками, свидетельствует о тяжелом испытании, которое выдерживали российские банки в 1917 г. Их связи с промышленными предприятиями, операции по их финансированию не преследовали долговременных целей, носили пассивный характер. О хотя бы большом промышленном оживлении, на которое надеялись капиталисты, предприниматели через пару месяцев после изменений в государственной власти переставали даже мечтать. Число этих людей было в масштабах страны очень небольшим. Ведущие политики считали, что можно «составить список «пяти или даже трех тысяч» самых богатых людей в России», связанных с банковским, финансовым капиталом [Ленин, 1969, с. 109]. Отношения их с Временным правительством, казалось бы, теоретически могли «предотвратить неминуемую катастрофу», каким представлялся тем же современникам Октябрь 1917 г.

Профессора-экономисты подсчитали тогда, что к началу 1917 г. в стране имелось не менее 14-15 млрд руб. свободного капитала [Туган-Барановский, 1917, с. 25], что сово- 
купное богатство частных лиц доходило в это время до 50 млрд руб. [Цит. по: Волобуев, 1962, с. 313-314] и т. д.

К лету 1917 г. политический процесс в России стал стремительно утрачивать общенациональный характер. Финансовая сфера ощутила этот перелом, разочаровываясь в правительстве, в его способности «рулить обществом». Она не хотела ждать, пока политические силы определятся в поисках консенсуса друг с другом. На арену выходили экономически наиболее развитые петроградские и московские предприниматели [Крузе, 1967, с. 390-392 и др.]. Их интересы как «своего класса» в правительстве предоставляли два министра - М.И. Терещенко и Н.В. Некрасов, и влияние этих богатых людей нельзя преуменьшать.

Однако многие разбогатевшие, не видя возможностей сохранения и умножения капитала внутри страны, стали скрывать капиталы припрятыванием крупных денежных купюр в несгораемых шкафах (тогда неожиданно стали исчезать из обращения купюры достоинством в 100 и 1000 руб.), другие стали активно снимать часть капиталов со счетов и депозитов. Пробный шар этими людьми был брошен весной 1917 г., а с апреля уже начался отлив денег за границу, который к октябрю 1917 г. принял огромные размеры [Прокопович, 1918, с. 113; Экономическое положение, 1957, с. 363, 380]. Для банков «бегство капиталов» за границу было средством валютной спекуляции, для каждого отдельного капиталиста - мерой предосторожности. Размеры утечки не поддаются подсчетам. В некоторых работах на основании соответствующих документов сказано, что они составили не один десяток миллионов рублей [Экономическое положение, 1957, с. 389].

Министерство финансов тогда, весной, было встревожено «утечкой» капиталов. 5 июня 1917 г. при министре А.И. Шингареве вышло постановление, запрещавшее денежные переводы за границу. Оно фактически коснулось в основном «средних» капиталистов. И нарушения такого рода с сентября стали принимать очень большие размеры, а запрещение стало благополучно обходиться самими чиновниками финансовых ведомств, предлагавшими содействовать переводам [Бурышкин, 1954, с. 339]. 17 октября 1917 г. Кредитной канцелярией Министерства финансов был издан циркуляр, который в дополнение к постановлению 5 июня устанавливал контроль над продажей банками своим клиентам наличной валюты, «ибо продажа ее, хотя бы и клиентам в России, рано или поздно влечет перевод денег за границу» [Голицын, Петров, 2017, с. 395]. Это был глас вопиющего в пустыне.

Развал российской экономики, нарастание хозяйственного кризиса в стране отражались и в деятельности Министерства финансов во Временном правительстве. У него плохо выходило искать новые источники дохода, «не переобременявшие трудящиеся массы и не подрывающие народное хозяйство» (как эмиссия и займы) [Волобуев, 1962, с. 313 и др.], к чему побуждала другая власть в стране - Советы рабочих и солдатских депутатов.

В 1917 г. масштабы бумажноденежной эмиссии и внутренних займов росли по ходу растущей дороговизной жизни. В апреле денежная эмиссия обнадеживающе снизилась до дореволюционного уровня, но вскоре ее темпы выросли, превзойдя дореволюционные показатели почти в четыре раза.

С марта по октябрь 1917 г. в стране было напечатано кредитных билетов царских образцов на 6412 млрд руб. Пребывание на посту министра финансов Некрасова знаменовалось и тем, что с августа 1917 г. правительством Керенского были пущены в обращение «собственные деньги» упрощенных до предела образцов и производства. Рисунки на них отражали время: кредитные билеты достоинством в 250 руб. были с двуглавым орлом, но без царских регалий - короны, скипетра и державы. 1000 руб. («думки») - с Таврическим дворцом в Петрограде. В сентябре появились казначейские знаки в 20 и 40 руб. («керенки»). Эти деньги печатались на плохой бумаге, не имели ни номера, ни подписей, ни даты, что вскоре и породило массовый выпуск фальшивых денег.

В 1917 г. сумма эмитированных Временным правительством бумажных денег зашкаливала за 9533 млрд руб., т. е. оказалось больше, чем за два с половиной предыдущих 
года войны. Оно оставляло далеко позади царское правительство, позволившее расширить эмиссионное право лишь на 6,2 млрд руб. Министерство финансов отмечало, что выпуск кредитных билетов зависел главным образом от военных расходов [Волобуев, 1962, c. 335-338; Голицын, Петров, 2017, с. 385; Гусаков, 1946]. Общая сумма бумажных денег к Октябрьскому перевороту возросла до 19574 млрд руб. С горечью современники признавали, что экспедиция изготовления государственных бумаг была единственным промышленным производством, не сократившим после февраля ни интенсивности труда, ни размеров производства. По подсчетам экономиста К.Ф. Шмелева, за весь 1917 г. выпусками бумажных денег было покрыто 65,5 \% военных расходов против 21,6\% в 1914-1916 гг. [Денежное обращение, 1922, с. 17]. Он уточнил подсчеты Г.Д. Дементьева, который считал, что в это время внутренними и внешними займами было покрыто 68 \% военных расходов [Дементьев, 1917, с. 38].

Наполнение торгового оборота бумажными деньгами подстегивало инфляцию, сопровождавшуюся спадом производства, ростом товарных цен, катастрофическим падением рубля, покупательная способность которого упала к октябрю 1917 г. до 6-7 коп. от довоенного уровня. Из-за падения курса рубля реальная стоимость денежной массы при гигантской эмиссии сократилась с 3,2 млрд довоенных золотых рублей до 1,9 млрд руб. Увеличение денежной массы на 1 \% сопровождалось ростом цен на 5,4 \%.

Население пугал опережающий инфляцию рост товарных цен: за второе полугодие 1917 г. количество денег в обращении по сравнению с началом 1914 г. выросло в 8,2 раза, индекс товарных цен - в 11,7 раза. Дефицит платежных средств привел к выпуску на местах торговыми, кооперативными организациями своих местных чеков и марок. К осени 1917 г. почти прекратился возврат денег в казну. Из почти 20 млрд денежных знаков, выпущенных при Временном правительстве, на руках у населения оставалось около 13-14 млрд. Имущие слои предпочитали припрятывать крупные купюры царских бумажных денег. Они быстрее обесценивались, чем печатались. Газеты писали, что стоимость рубля может сравняться со стоимостью бумаги, на которой он был напечатан. Остановка печатного станка была бы полным банкротством, прекращением снабжения армии и полным военным поражением. Правительство намечало грандиозный выпуск бумажных денег до конца года до 6 млрд рублей.

Надежды на внутренние займы у всех министров финансов Временного правительства, как было замечено выше, не оправдывались. Дважды продлевались сборы подписей «Займа Свободы», но ничего не вышло. Займ был провален, в том числе и имущими сословиями, которые все меньше старались перепоручить свои капиталы государству во имя войны до победного конца и восстановления «порядка». Сколько коммерческие банки ни группировали подписчиков, усилия их были тщетны: крупные представители капитала сомневались, как тогда выражалась их печать, в «социалистическом эксперименте» первого коалиционного правительства. Займы продвигались плохо в условиях падения заработной платы на всех производствах, сокращения численности рабочих и роста числа безработных.

Замечу, что после июльского кризиса и появления на горизонте Корнилова сумма подписки среди представителей капитала несколько возросла, но вскоре она спала и далее колебалась в зависимости от степени доверия капитала к власти. Именно банки вступали в конфронтацию с властью и «во многом предопределили падение неугодного им первого коалиционного кабинета» [Волобуев, 1962, с. 343-348], переход демократического правительства с большим процентом социалистов чуть ли не к открытой контрреволюции.

В последние месяцы Временного правительства, как сообщала 4 октября 1917 г. «Финансовая газета», биржа вовсе перестала покупать кредитные билеты, предпочитая сохранять свои собственные ценности.

В портфеле сберегательных касс с июня 1914 г. по октябрь 1917 г. находилось государственных займов военного времени на сумму более 3,2 млрд рублей. Но возникали проблемы с выдачей зарплаты на многих производствах. Народ проклинал власть, сравни- 
вая ее с царскими временами не в ее пользу. Единственным выходом в спасении народного хозяйства могла быть только национализация банков [Экономическое положение, 1957 , c. 363-364; Волобуев, 1962, с. 360-364; Голицын, Петров, 2017, с. 385-387; Бокарев, 2014, 311-313].

Находясь в сжимавшихся тисках внутри страны, Временное правительство продолжало быть верным союзническим обязательствам Антанты, но там отношения были не равными партнерскими.

С этой целью в первом составе правительства министру финансов М.И. Терещенко было предоставлено право на необходимые кредитные операции за границей в пределах до 10 млрд руб. под гарантии краткосрочных обязательств Государственного казначейства в иностранной валюте [Голицын, 1998, с. 105]. Министерство финансов надеялось на расширение заимствований у союзников на войну. «Не будь их..., войну мы должны были бы прекратить», - заявил летом 1917 г. тогда еще советник в правительстве М.В. Бернацкий [Стенографический..., № 3, 1917, с. 19]. Временное правительство льстило себя надеждой, что «отмена старого режима благоприятным образом скажется на кредитоспособности иностранных государств» [Архив, 2001, с. 26]. У него стояла задача «доказать» союзникам рвение России продолжать войну, не потерять их доверие в способности справиться с революцией.

Союзники же стремились, воспользовавшись ситуацией, низводя Россию до роли покорного сателлита [Сидоров, 1960, с. 506-510], очень боясь сепаратного мира, даже открывали новые каналы финансирования, имея главную цель - всемерно препятствовать его заключению Россией [Голицын, 1998, с. 103].

За счет иностранных кредитов Россия и оплачивала поставки вооружения, и, одновременно поддерживая курс русской валюты на зарубежных рынках, производила выплату процентов по государственному долгу. Но из этих средств ни разу ничего не перепадало тылу.

Англия, осторожничая, остерегаясь неблагоприятного разрешения революционной ситуации, давала кредиты в весьма ограниченных размерах. За восемь месяцев 1917 г. она выплатила Временному правительству 408 млн руб., значительно меньше того, сколько получало имперское правительство. От Франции Временному правительству пришлось довольствоваться только тем, что было обещано царизму - скромная сумма в 300-350 млн руб. теперь выдавалась в течение марта - октября 1917 г.

На одном из первых заседании Временного правительства возник вопрос об использовании американского и японского денежного рынка. США ограничились лишь обещанием прямых американских кредитов в 325 млн дол. Но Америкой было отпущено с апреля до октября 1917 г. в разные сроки лишь 187,7 млн долларов под 3,5\%-ные обязательства русского Государственного казначейства [Волобуев, 1962, с. 371, 374-377 и др.]. В Японию для обеспечения поставок вооружения отправлялось «залоговое золото», но Япония об этом «забыла», предъявив после 1917 г. России долг в 297,7 млн иен [Голицын, Петров, 2017, с. 398]. О получении кредита при депонировании на 5 млн руб. золота из Государственного банка Временнее правительство вело переговоры и со Швецией. Золото Швеция получила, но России получить хотя бы часть кредита у этой страны не удалось: нагрянула новая революция, и это тоже «забылось» [Голицын, Петров, 2017, с. 400-401].

О размере госдолга России к Октябрю 1917 г. у историков нет единого общепринятого мнения. Известно, что за 2,5 года войны союзниками еще царскому правительству было выделено 5,2 млрд руб. Временное правительство получило от них примерно 2 млрд (2 034,1 млн) руб., т. е. на 1 млрд меньше, чем царизм в течение одного 1916 г.) [Экономическое положение, 1957, с. 384; Волобуев, 1962, с. 378; Голицын, 1998, с. 103].

Подсчетами государственного долга России к концу Февральской революции занимались многие историки. Бытует последнее мнение, что накануне октября 1917 г. государственный долг России (с учетом краткосрочных обязательств казначейства) превышал 60 млрд руб., в т. ч. внутренний долг составлял 44 млрд; тогда как внешняя (заграничная) 
задолженность составляла от 7,2 млрд до 16 млрд руб. Подсчетом величины и характера госдолга России к концу 1917 г. занимались И.Ф. Гиндин, П.В. Волобуев, А.Л. Сидоров, П.М. Золин [Гиндин, 1957, с. 166-172; Золин, 1991 с. 82].

В экономическом отношении внешние долги «весили» гораздо больше, чем внутренняя заложенность. В войну бумажный рубль по сравнению с довоенным золотым рублем обесценился почти в 15 раз, тогда как подавляющая часть заграничных займов была заключена в золотых рублях или в валюте [Голицын, Петров, 2017, с. 401]. Однако без реальных союзнических кредитов Россия не могла продолжать войну.

Россия считалась на Западе надежным и аккуратным заемщиком. У нее был большой золотой запас, который при Временном правительстве уменьшился незначительно: с 3618 млрд руб. до 3605 млрд руб. [Голицын, 1998, с. 103]

На этих цифрах нельзя остановиться без пояснений. Замечу, прямой государственный долг России за восемь месяцев распоряжающимся государственной казной Временным правительством увеличился на 14,4 млрд руб. Эта сумма составляла более трети его прироста за годы войны до Октября 1917 г. и более половины прироста за 32 месяца ведения войны царским правительством. С марта 1917 г. государственный долг возрастал в среднемесячном исчислении в 2,5 раза быстрее, чем до Февраля 1917 г. [Волобуев, 1962, с. 380-381; Сидоров, 1960] К концу 1917 г. Россия задолжала разные суммы 13 странам, включая отошедшую от нее тогда полностью Финляндию. На момент национализации предприятий (по данным П.В. Оля) - 78,7 \% составляли долги всем странам, входившим в состав Антанты (из них 16,1 \% составляли германские и австрийские капиталы) [Оль, 1925].

Главным фактором возрастания государственного долга был большой внутренний долг, связанный с колоссальной денежной эмиссией, займовыми операциями казны на внутреннем рынке [Сидоров, 1960, с. 517-518]. Никаких долгосрочных внешних займов Временное правительство не получало; миллиардные займы союзников были оформлены как краткосрочные кредиты, обеспеченные краткосрочными обязательствами Государственного казначейства России.

Финансовое положение России к осени 1917 г. действительно стало катастрофическим. Восемь месяцев после Февраля 1917 г. «оказались периодом нараставшего жесточайшего финансово-экономического кризиса, усугубляемого растущей общественнополитической нестабильностью» [Российская революция, 2017, с. 562]. В разной степени вся система Временного правительства в 1917 г. при всех своих составах и во всех министерствах стремилась сохранить учрежденческие и прочие контракты со старым имперским режимом. Это отчетливо проявилось и в финансовой его политике - бессилие Временного правительства становилось очевиднее, если видеть бесплодные в итоге усилия разных министров финансов в течение восьми месяцев 1917 г. Замечу, что эта тема как специальная обойдена пока историками.

России предстояла расплата за долги, в которых она достаточно сильно увязла. Платежи по погашению должны были составить 2,4 млрд руб. в год. Заграничные в них (по подсчетам в июле 1917 г. Г.Д. Дементьева) составляли 560 млн руб. золотом, тогда как доходы по «мирному» бюджету в 1913 г. равнялись 3,4 млрд руб. [Стенографический ... № 5, 1917, с. 5]. Для России это означало усиление финансово-экономической зависимости от Запада, а в случае победы в войне Антанты в будущем было чревато их вмешательством во внутреннюю экономическую жизнь России.

На это указывал в Европе уже созданный Межсоюзнический комитет [Сидоров, 1960, с. 506-512]. В его планы входило организовать дела так, чтобы был свободный доступ в Россию иностранного, главным образом американского капитала, нацеленного на эксплуатацию природных богатств России.

Особое совещание по горным делам Временного правительства уже вынесло решение отдать «как чисто деловому и аполитичному» американскому капиталу договоры на эксплуатацию, концессии в России - на нефтепромышленность на о. Сахалин, углепро- 
мышленность на Дальнем Востоке, на крупное золотоносное дело в Сибири, золоторудное дело на Алтае, железорудное дело на Южном Урале, на Подмосковный уголь, на карьерную и цементную промышленность, на кавказскую медь и марганец, на курортное дело и электрификацию ряда районов. Общая сумма иностранных капиталов, необходимых для горнозаводской промышленности, определялась в 10 млрд руб. [Экономическое положение, 1957, с. 464]. Программа распродажи национальных богатств была уготовлена стране после Учредительного собрания.

Выйти из сложившейся зависимости России от других стран, остановить кровопускание в ее финансовой системе, на которой зиждилась вся ее экономика, могли только радикальные повороты государственной власти. Каким было бы это правительство, не случись социалистической революции, трудно сказать. В существовавшей системе двоевластия в 1917 г. все составы Временного правительства не вселяли надежду. Слово было теперь за народной властью.

Итогом участия России в войне и революций был очевидный факт, озвученный летом 1918 г. на І съезде Советов народного хозяйства: «Мы должны сознаться, конечно, что наша финансовая система и банковский аппарат разрушены» [Труды, 1918, с. 326].

Новейшая историография подчеркивает, что на первое место Советская власть после 25 октября поставила подчинение ей банковского аппарата [Голицын, Петров, 2017, c. 403-411], что и было сделано и определило дальнейший ход событий - истории с Учредительным собранием, Викжелем и т.д. Национализация банков в 1918 г. прекратила «бегство капиталов» заграницу, которое началось еще в сентябре 1917 г. и активизировалось после октябрьских событий.

Общим местом в советской экономической и историографической литературе в истории финансов периода Первой мировой войны, напоминают Ю.А. Петров и Ю.П. Голицын, всегда был главный тезис: задача Советской власти состояла в том, чтобы обеспечить безусловное соблюдение интересов малоимущих граждан, владеющих облигациями аннулированных займов, сделать все, чтобы они не пострадали от новой финансовой политики. Исходя из этого, дается здравомыслящая оценка проведенного новой властью «дефолта» в 1918 г., так называемой «красногвардейской» атаке на российский и международный капитал [Голицын, Петров, 2017, с. 423].

Замечу, что стремительная, испепеляющая, бессистемная атака Советов на имущие классы под лозунгом «грабь награбленное у народа» имела многие отрицательные стороны. Под право «обложения имущих классов» массово попадали не только толстосумы города и деревни, но и среднее крестьянство, простые горожане, государственные служащие [Голицын, Петров, 2017, с. 412-413].

Бесконтрольность Советов в расходовании полученных ими средств рождала негативное отношение к ним населения страны. Атака в международной сфере явилась отказом Советов от принятых Россией договорных финансовых обязательств прежних ее правительств. Еще в декабре 1917 г. Советское правительство зондировало почву в отношении «государственного банкротства», его декретом 21 января 1918 г. были аннулированы все иностранные государственных долги России и иностранные займы как «капиталистические», в результате чего банки Германии, Великобритании, Франции, всех стран, которым была должна Россия, теряли огромные суммы, также как держатели русских государственных займов и облигаций железных дорог. Это вызвало бурную реакцию в мире. Проблема обсуждалась на дипломатическом уровне на протяжении всей истории существования СССР [Голицын, Петров, 2017, c. 417-418, 424 и др.]. Но это уже другая тема, которую до́лжно рассматривать в связи со всей предысторией финансового положения России в имперский период и последующие восемь месяцев Временного правительства, признав со всей частностью, что в мировую войну Россия сильно проиграла финансово-экономически и морально.

Историография России в 1917 г. не может отказаться от вывода о неизбежности социалистической революции. Альтернатива этому - подчеркивают новейшие работы - 
находится «в непосредственной зависимости от состояния политической системы и позиции ее ведущих акторов, включая российского императора» [Шелохаев, Соловьев, 2008, с. 163]. Обращаясь к проблеме власти и общества в атмосфере формирования в народе революционного сознания в России в начале XX в., Д.И. Менделеев записал в трактате «Заветные мысли», что «только богатое государство, у которого налажено финансирование (подчеркнуто мною И.П.), связанная с ним промышленность и товарное производство, может удовлетворить и элиту, и народ. Организованная государственным управлением финансовая система всегда в ответе за народную нищету, за модернизацию как производства, так и за состояние всего общества в целом» [Цит. по: Китанина, 2016, с. 57-58].

История финансов в Первую мировую войну и революции 1917 г. в России, тесно переплетаясь с историей экономики, помогает определить угол зрения в объяснении причин этих революций, поясняя и крах монархии, над которым размышляет не одно поколение историков в поисках ответа на вопрос: могла ли Россия избежать трагедию 1917 г.?

\section{Список литературы}

1. Аничков В.П. 1998. Екатеринбург - Владивосток (1917-1922). М., Русский путь, 366.

2. Архив новейшей истории России. 2001. Серия «Публикации». T. VII. Журналы заседаний Временного правительства: Март - октябрь 1917 года. В 4-х т. Том 1. Март - апрель 1917 года. М., РОССПЭН, 447.

3. Боголепов Д.П. 1917. Война и финансы. М., 31.

4. Бокарев Ю.П. 2014. Денежное обращение. Россия в Первой мировой войне. 1914-1918: Энциклопедия. 1: 608-613.

5. Бурышкин П.А. 1954. Москва купеческая. Нью-Йорк, 349.

6. Вестник Временного правительства. 11 марта 1917 г.

7. Вознесенский С.В. 2009. Первые сто лет. Экспедиции изготовления государственных бумаг, 1818-1918. СПб., Нестор-История, 426.

8. Волобуев П.В. 1962. Экономическая политика Временного правительства. М., Издательство Академии наук СССР, 483.

9. Вопросы финансовой реформы в России. В 3-х т. Т. 2. Вып. 1. М., 1916. 139.

10. Гиндин И.Ф. 1957. О величине и характере русского государственного долга в конце 1917 г. История СССР. 5: 166-172.

11. Голицын Ю.П. 1998. Фондовый рынок дореволюционной России: очерки истории. М., Деловой экспресс, 279.

12. Голицын Ю.П., Петров Ю.А. 2017. Финансовое положение. Февраль 1917 - осень 1918 г. В кн.: Российская революция 1917 г.: власть, общество, культура: в 2-х т. Отв. ред. Ю.А. Петров. Т. 1. М., РОССПЭН, 384-453.

13. Гусаков А.Д. 1946. Очерки по денежному обращению в России накануне и в период Октябрьской социалистической революции. М., Госфиниздат, 124.

14. Дементьев Г.Д. 1917. Государственные доходы и расходы России и положение Государственного казначейства за время войны с Германией и Австро-Венгрией до конца 1917 г. Пг., тип. ред. период. изд. М-ва Финансов, 54.

15. Денежное обращение и кредит. Т. 1. Денежное обращение в России и за границей в годы войны и революции (1914-1921 гг.): [Сб. ст.]. Под ред. С.В. Воронина и К.Ф. Шмелева. Пг.: Б. и., 1922. 638 .

16. Денисов А.Е. 2005. Государственные займы Российской империи 1798-1917 годов. М., Финансы и кредит, Финансовая инновационная компания «Фининнова», 211.

17. Дьяченко В.П. 1947. Советские финансы в первой фазе развития социалистического государства. Ч. І. 1917-1925. М., Госфиниздат, 476.

18. Ефимкин А.П. 1988. Отправка Временным правительством золота в Швецию. Вопросы истории. 12: 105-110.

19. Золин П.М. 1991. Государственный долг: истоки тенденции. Финансы СССР. 4.

20. История Банка России, 1860-2010: в 2-х т. Отв. ред. Ю.А. Петров, С.В. Татаринов. М., РОССПЭН, 2010. $623+679$. 
21. Китанина Т.М. 2016. Россия в первой мировой войне. Экономика и экономическая политика. 1914-1917 гг. Курс лекций. Изд. 2-ое. СПб., Гуманитарная академия, 348.

22. Коняев А.И. 1959. Финансовый контроль в дореволюционной России: (Очерки истории). М., Госфиниздат, 164.

23. Крузе Э.Э. 1967. Экономика Петрограда в первой половине 1917 г. В кн.: Октябрьское вооруженное восстание. 1917 год в Петрограде. Кн. ІІ. На путях к социалистической революции. Двоевластие. Л., Наука. Ленингр. отд-ние.

24. Ленин В.И. 1969. Неминуемая катастрофа и безмерные обещания. В кн.: Ленин В.И. Полное собрание сочинений. Т. 32. Май - июль 1917. М., Издательство политической литературы: $105-111$.

25. Мошенский С.3. 2014. Рынок ценных бумаг Российской империи. М., Экономика, 560.

26. Оль П.В. 1925. Иностранные капиталы в народном хозяйстве довоенной России. Л., 35.

27. Особые совещания и комитеты военного времени. Пг., Гос. тип., 1917. 99.

28. Петров Ю.А. 2000. Проблема государственного долга и частные германские инвестиции в России. В кн.: Экономическая история России XIX-XX вв.: современный взгляд. М., РОССПЭН: $458-468$.

29. Погребинский А.П. 1968. Государственные финансы царской России в эпоху империализма. М., Финансы, 167.

30. Потемкин А.П. 1997. Государственные займы в период Временного правительства в 1917 г. Финансы. 1: 55-57.

31. Прокопович С.Н. 1918. Война и народное хозяйство. М., 264.

32. Пушкарева И.М. 1964. Всеобщая сентябрьская стачка железнодорожников в 1917 г. В кн.: Рабочий класс и рабочее движение в России в 1917 г. М., Наука: 180-202.

33. Ривкин Б.Б. 1957. Финансовая политика в период Великой Октябрьской социалистической революции. М., Госфиниздат. 319.

34. Российская революция 1917 г.: власть, общество, культура: в 2-х тт. Отв. ред. Ю.А. Петров. Т. 2. М., РОССПЭН, 2017. 591.

35. Сберегательные кассы во время Первой мировой войны. В кн.: История сберегательных касс России. 1841-1991. Под ред.А.И. Казьмина. М.: б/издательства: 160-169.

36. Сидоров А.Л. 1960. Финансовое положение России в годы Первой мировой войны. (1914-1917). М., Изд-во АН СССР, 579.

37. Сидоров А.Л. 1973. Экономическое положение России в годы Первой мировой войны. М., Наука, 655.

38. Стенографический отчет заседаний Экономического совета при Временном правительстве. № 3. Санкт-Петербург, 1917.

39. Стенографический отчет заседаний Экономического совета при Временном правительстве. № 5. Санкт-Петербург, 1917. $31-45$

40. Страхов В.В. 2007. «Заем свободы» Временного правительства. Вопросы истории. 10 :

41. Страхов В.В. 2006. Общественные проекты в сфере государственных финансов России 1914-1917 годов. Вопросы истории. 11: 21-38.

42. Суханов Н.Н. 1922. Записки о революции. Кн. 3. Берлин, 450.

43. Терещенко М. 2012. Первый олигарх: Михаил Иванович Терещенко (1886-1956): Необычайная история жизни моего деда, как ее рассказала бы мне моя бабушка. Киев, НикаЦентр, 228.

44. Труды 1 Всероссийского съезда советов народного хозяйства. 25 мая - 4 июня 1918 г.: (Стеногр. отчет). Москва. 1918. 488.

45. Туган-Барановский М.И. 1917. Военные займы в теоретическом освещении. В кн.: Военные займы: Сборник статей. Под общ. ред. М.И. Туган-Барановского. Пг., тип. «Правда», 5-25.

46. Тютюкин С.В. 2012. Александр Керенский. Страницы политической биографии (1905-1917). М., РОССПЭН, 309.

47. Ходяков М.В. 2009. Деньги революции и Гражданской войны: денежное обращение в России. 1917-1920 гг. СПб., Печатный двор им. А.М. Горького, 221.

48. Чубаков И.И. 1926. Внутренние и внешние кредитные операции в период империалистической войны. Вестник финансов. 5-6: 131-138. 
49. Шелохаев В.В., Соловьев К.А. 2018. Февраль в тени Октября (историографические итоги и исследовательские задачи). Российская история. 1: 161-171.

50. Шляпников А.Г. 1927. Семнадцатый год. Кн. 3. М., Л., 380.

51. Экономическое положение России накануне Великой Октябрьской социалистической революции. Документы и материалы. Март - октябрь 1917 г. Ч. 2. М., Л., Изд-во Акад. наук СССР, 1957. 655.

\section{References}

1. Anichkov V.P. 1998. Ekaterinburg - Vladivostok (1917-1922) [Yekaterinburg - Vladivostok (1917-1922)]. M., Russkij put', 366 (in Russian).

2. Arhiv novejshej istorii Rossii. 2001. Serija «Publikacii». T. VII. Zhurnaly zasedanij Vremennogo pravitel'stva: Mart - oktjabr' 1917 goda. V 4-h t. Tom 1. Mart - aprel' 1917 goda [Archive of the recent history of Russia. Series «Publications». T. VII. Journals of meetings of the Provisional Government: March - October 1917]. M., ROSSPJeN, 447 (in Russian).

3. Bogolepov D.P. 1917. Vojna i finansy [War and Finance]. M., 31 (in Russian).

4. Bokarev Ju.P. 2014. Denezhnoe obrashhenie. Rossija v Pervoj mirovoj vojne. 1914-1918 [Monetary Circulation. Russia in the First World War. 1914-1918]: Jenciklopedija. 1: 608-613 (in Russian).

5. Buryshkin P.A. 1954. Moskva kupecheskaja [Moscow merchant]. N'ju-Jork, 349. (in Russian).

6. Vestnik Vremennogo pravitel'stva [Bulletin of the Provisional Government]. 11marta $1917 \mathrm{~g}$.

7. Voznesenskij S.V. 2009. Pervye sto let. Jekspedicii izgotovlenija gosudarstvennyh bumag, 1818-1918 [The First Hundred Years. Expeditions of making government papers, 1818-1918]. SPb., Nestor-Istorija, 426 (in Russian).

8. Volobuev P.V. 1962. Ekonomicheskaja politika Vremennogo pravitel'stva [Economic Policy of the Provisional Government]. M., Izdatel'stvo Akademii nauk SSSR, 483 (in Russian).

9. Voprosy finansovoj reformy $v$ Rossii [Issues of financial reform in Russia]. V 3-h t. T. 2. Vyp. 1. M., 1916. 139 (in Russian).

10. Gindin I.F. 1957. O velichine i haraktere russkogo gosudarstvennogo dolga v konce $1917 \mathrm{~g}$. [About the size and nature of the Russian state debt at the end of 1917] Istorija CCCR. 5: 166-172 (in Russian).

11. Golicyn Ju.P. 1998. Fondovyj rynok dorevoljucionnoj Rossii: ocherki istorii [The stock market of pre-revolutionary Russia: history essays]. M., Delovoj ekspress, 279 (in Russian).

12. Golicyn Ju.P., Petrov Ju.A. 2017. Finansovoe polozhenie. Fevral' 1917 - osen' 1918 g. [Financial situation. February 1917 - autumn 1918]. V kn.: Rossijskaja revoljucija 1917 g.: vlast', obshhestvo, kul'tura: v 2 -h t. [In the book: Russian revolution of 1917: power, society, culture: in 2 vols]. Otv. red. Ju.A.Petrov. T. 1. M., ROSSPJeN: 384-453 (in Russian).

13. Gusakov A.D. 1946. Ocherki po denezhnomu obrashheniju v Rossii nakanune i v period Oktjabr'skoj socialisticheskoj revoljucii [Essays on money circulation in Russia on the eve and during the October Socialist Revolution]. M., Gosfinizdat, 124 (in Russian).

14. Dement'ev G.D. 1917. Gosudarstvennye dohody i rashody Rossii i polozhenie Gosudarstvennogo kaznachejstva za vremja vojny s Germaniej i Avstro-Vengriej do konca 1917 g. [State revenues and expenditures of Russia and the position of the State Treasury during the war with Germany and AustriaHungary until the end of 1917]. Pg., tip. red. period. izd. M-va Finansov, 54 (in Russian).

15. Denezhnoe obrashhenie i kredit. T. 1. Denezhnoe obrashhenie v Rossii i za granicej v gody vojny i revoljucii (1914-1921 gg.) [Money circulation and credit. T. 1. Money circulation in Russia and abroad during the war and revolution (1914-1921)]: [Sb. st.]. Pod red. S.V. Voronina i K.F. Shmeleva. Pg.: B. i., 1922, 638 (in Russian).

16. Denisov A.E. 2005. Gosudarstvennye zajmy Rossijskoj imperii 1798-1917 godov [State loans of the Russian Empire 1798-1917]. M., Finansy i kredit, Finansovaja innovacionnaja kompanija «Fininnova», 211 (in Russian).

17. D'jachenko V.P. 1947. Sovetskie finansy v pervoj faze razvitija socialisticheskogo gosudarstva. Ch. I. 1917-1925 [Soviet finance in the first phase of the development of the socialist state. Part I. 1917-1925]. M., Gosfinizdat, 476 (in Russian).

18. Efimkin A.P. 1988. Otpravka Vremennym pravitel'stvom zolota v Shveciju [Sending gold by the Provisional Government to Sweden]. Voprosy istorii. 12: 105-110 (in Russian). 
19. Zolin P.M. 1991. Gosudarstvennyj dolg: istoki tendencii [Public Debt: The Origins of the Trend]. Finansy SSSR. 4 (in Russian).

20. Istorija Banka Rossii, 1860-2010: v 2-h t. [History of the Bank of Russia, 1860-2010: in 2 vols]. Otv. red. Ju.A. Petrov, S.V. Tatarinov. M., ROSSPJeN, 2010. $623+679$ (in Russian).

21. Kitanina T.M. 2016. Rossija v pervoj mirovoj vojne. Jekonomika i jekonomicheskaja politika. 1914-1917 gg. [Russia in the First World War. Economics and economic policy. 1914-1917 Lecture course]. Kurs lekcij. Izd. 2-oe. SPb., Gumanitarnaja akademija, 348 (in Russian).

22. Konjaev A.I. 1959. Finansovyj kontrol'v dorevoljucionnoj Rossii: (Ocherki istorii) [Financial control in pre-revolutionary Russia: (Essays on history)]. M., Gosfinizdat, 164 (in Russian).

23. Kruze Je.Je. 1967. Jekonomika Petrograda v pervoj polovine 1917 g. [Economy of Petrograd in the first half of 1917]. V kn.: Oktjabr'skoe vooruzhennoe vosstanie. 1917 god v Petrograde. Kn. II. Na putjah k socialisticheskoj revoljucii. Dvoevlastie [In the book: October armed uprising. 1917 in Petrograd. Book II. On the road to the socialist revolution. Dual power]. L., Nauka. Leningr. otd-nie. (in Russian).

24. Lenin V.I. 1969. Neminuemaja katastrofa i bezmernye obeshhanija [Inevitable Catastrophe and Immeasurable Promises]. V kn.: Lenin V.I. Polnoe sobranie sochinenij. T. 32 . Maj - ijul' 1917 [In the book: Lenin V.I. Full composition of writings. T. 32. May - July 1917]. M., Izdatel'stvo politicheskoj literatury: 105-111 (in Russian).

25. Moshenskij S.Z. 2014. Rynok cennyh bumag Rossijskoj imperii [The Securities Market of the Russian Empire]. M., Jekonomika, 560 (in Russian).

26. Ol' P.V. 1925. Inostrannye kapitaly v narodnom hozjajstve dovoennoj Rossii [Foreign capital in the national economy of pre-war Russia]. L., 35 (in Russian).

27. Osobye soveshhanija i komitety voennogo vremeni [Special meetings and wartime committees]. Pg., Gos. tip., 1917, 99 (in Russian).

28. Petrov Ju.A. 2000. Problema gosudarstvennogo dolga i chastnye germanskie investicii v Rossii [The Problem of Public Debt and Private German Investment in Russia]. V kn.: Jekonomicheskaja istorija Rossii XIX-XX vv.: sovremennyj vzgljad [In the book: Economic history of Russia XIX - XX centuries: modern view]. M., ROSSPJeN: 458-468 (in Russian).

29. Pogrebinskij A.P. 1968. Gosudarstvennye finansy carskoj Rossii v jepohu imperializma [State finances of tsarist Russia in the era of imperialism]. M., Finansy, 167 (in Russian).

30. Potemkin A.P. 1997. Gosudarstvennye zajmy v period Vremennogo pravitel'stva v $1917 \mathrm{~g}$. [State loans during the Provisional Government in 1917]. Finansy. 1: 55-57 (in Russian).

31. Prokopovich S.N. 1918. Vojna i narodnoe hozjajstvo [War and the National Economy]. M., 264 (in Russian).

32. Pushkareva I.M. 1964. Vseobshhaja sentjabr'skaja stachka zheleznodorozhnikov v 1917 g. [The general September strike of railway workers in 1917]. V kn.: Rabochij klass i rabochee dvizhenie v Rossii v 1917 g. [In the book: The working class and the labor movement in Russia in 1917]. M., Nauka: 180-202 (in Russian).

33. Rivkin B.B. 1957. Finansovaja politika v period Velikoj Oktjabr'skoj socialisticheskoj revoljucii [Financial policy during the Great October Socialist Revolution]. M., Gosfinizdat. 319 (in Russian).

34. Rossijskaja revoljucija 1917 g.: vlast', obshhestvo, kul'tura: v 2-h t. [The Russian revolution of 1917: power, society, culture: in 2 vols]. Otv. red. Ju. A. Petrov. T. 2. M., ROSSPJeN, 2017. 591 (in Russian).

35. Sberegatel'nye kassy vo vremja Pervoj mirovoj vojny [Savings banks during the First World War]. V kn.: Istorija sberegatel'nyh kass Rossii. 1841-1991. Pod red. A.I. Kaz'mina [In the book: History of savings banks in Russia. 1841-1991]. M.: b/izdatel'stva: 160-169 (in Russian).

36. Sidorov A.L. 1960. Finansovoe polozhenie Rossii v gody Pervoj mirovoj vojny (1914-1917) [The financial position of Russia during the First World War (1914-1917)]. M., Izd-vo AN SSSR, 579 (in Russian).

37. Sidorov A.L. 1973. Jekonomicheskoe polozhenie Rossii v gody Pervoj mirovoj vojny [The economic situation in Russia during the First World War]. M., Nauka, 655 (in Russian).

38. Stenograficheskij otchet zasedanij Jekonomicheskogo soveta pri Vremennom pravitel'stve [Verbatim record of meetings of the Economic Council under the Provisional Government]. № 3. SanktPeterburg, 1917 (in Russian).

39. Stenograficheskij otchet zasedanij Jekonomicheskogo soveta pri Vremennom pravitel'stve [Verbatim record of the meetings of the Economic Council under the Provisional Government]. № 5. Sankt-Peterburg, 1917 (in Russian).

40. Strahov V.V. 2007. «Zaem svobody» Vremennogo pravitel'stva [«Loan of Freedom» of the Provisional Government]. Voprosy istorii. 10: 31-45 (in Russian). 
41. Strahov V.V. 2006. Obshhestvennye proekty v sfere gosudarstvennyh finansov Rossii 1914-1917 godov [Public Projects in the Sphere of Public Finance of Russia 1914-1917]. Voprosy istorii. 11: 21-38 (in Russian).

42. Suhanov N.N. 1922. Zapiski o revoljucii [Notes on the Revolution]. Kn. 3. Berlin, 450.

43. Tereshhenko M. 2012. Pervyj oligarh: Mihail Ivanovich Tereshhenko (1886-1956): Neobychajnaja istorija zhizni moego deda, kak ee rasskazala by mne moja babushka [The first oligarch: Mikhail Ivanovich Tereshchenko (1886-1956): An extraordinary story of my grandfather's life, as my grandmother would tell me]. Kiev, Nika-Centr, 228.

44. Trudy 1 Vserossijskogo s'ezda sovetov narodnogo hozjajstva. 25 maja - 4 ijunja 1918 g.: (Stenogr. otchet) [Proceedings of the 1st All-Russian Congress of Councils of the National Economy. May 25 - June 4, 1918: (Verbatim report)]. Moskva. 1918. 488 (in Russian).

45. Tugan-Baranovskij M.I. 1917. Voennye zajmy v teoreticheskom osveshhenii [War loans in theoretical coverage]. V kn.: Voennye zajmy: Sbornik statej [In the book: War loans: Collection of articles]. Pod obshh. red. M.I. Tugan-Baranovskogo. Pg., tip. «Pravda»: 5-25 (in Russian).

46. Tjutjukin S.V. 2012. Aleksandr Kerenskij. Stranicy politicheskoj biografii (1905-1917) [Alexander Kerensky. Pages of political biography (1905-1917)]. M., ROSSPJeN, 309 (in Russian).

47. Hodjakov M.V. 2009. Den'gi revoljucii i Grazhdanskoj vojny: denezhnoe obrashhenie v Rossii 1917-1920 gg. [Money of the Revolution and the Civil War: Money Circulation in Russia 1917-1920]. SPb., Pechatnyj dvor im. A.M. Gor'kogo, 221 (in Russian).

48. Chubakov I.I. 1926. Vnutrennie i vneshnie kreditnye operacii v period imperialisticheskoj vojny [Internal and external credit operations during the imperialist war]. Vestnik finansov. 5-6: 131-138 (in Russian).

49. Shelohaev V.V., Solov'ev K.A. 2018. Fevral' v teni Oktjabrja (istoriograficheskie itogi i issledovatel'skie zadachi) [February in the shadow of October (historiographic results and research tasks)]. Rossijskaja istorija. 1: 161-171 (in Russian).

50. Shljapnikov A.G. 1927. Semnadcatyj god. Kn. 3 [The seventeenth year]. M., L., 380 (in Russian).

51. Jekonomicheskoe polozhenie Rossii nakanune Velikoj Oktjabr'skoj socialisticheskoj revoljucii. Dokumenty i materialy. Mart - oktjabr' 1917 g. Ch. 2. [The economic situation in Russia on the eve of the Great October Socialist Revolution. Documents and materials. March - October 1917. Part 2]. M., L., Izd-vo Akad. nauk SSSR, 1957, 655 (in Russian).

\section{ИНФОРМАЦИЯ ОБ АВТОРЕ}

Пушкарёва Ирина Михайловна, доктор исторических наук, ведущий научный сотрудник, Центр истории России XIX - начала XX в., Институт российской истории Российской академии наук, г. Москва, Россия

\section{INFORMATION ABOUT THE AUTHOR}

Pushkareva Irina Mikhailovna, Doctor of Historical Sciences, Leading Researcher, Center for the History of Russia in the end of XIXth - beginning of the XXth century, Institute of Russian History, Russian Academy of Sciences, Moscow, Russia 